\title{
Digital Payment Systems: Global Opportunities Still Waiting to be Unleashed
}

\author{
Dr. Ali M. Al-Khouri \\ Director General, Emirates Identity Authority, Abu Dhabi, UAE \\ Professor of Identity and Security, British Institute of Technology and E-commerce, London, UK \\ E-mail: ali.alkhouri@emiratesid.ae
}

Received: August 5, 2014 Accepted: August 26, 2014

doi:10.5296/ber.v4i2.6296 URL: http://dx.doi.org/10.5296/ber.v4i2.6296

\begin{abstract}
Advances in the field of digital payment methods have fundamentally changed their operation. These technological progressions have helped bring safer, cheaper, more stable and all-inclusive payment systems to the world. This paper provides a brief overview of digital payment systems. It also argues that government identity managements systems have a potential role in supporting more trusted and secure digital payments. It relates this to a pilot project underway in the United Arab Emirates (UAE) that attempts to leverage its government identity management system to encourage wider participation in the national Wages Protection System (WPS).
\end{abstract}

Keywords: Digital payments, Electronic payments, Financial systems, Identity management, Digital identity, Identification, Authentication

\section{Introduction}

Paper money and coins (cash) are still the primary global payment methods, and are widely viewed as the physical portrayal of prosperity. The use of physical money is an act based on social behaviour rather than technology. Cash, while it can hide the user's identity, it has its limitations in availability and transportability (European Central Bank, 2014). Furthermore, with a rise in purchases through digital means, cash is seen rather an obstacle to conduct transactions through these faraway and virtual channels quickly (Al-Khouri, 2014a; European Central Bank, 2012).

According to financial experts, the world is expected to witness an explosion of noncash transactions in low-and middle-income countries, accompanied by a much smaller increase in high-income countries (Menon et al., 2013). See Figure 1. They argue that the proliferation of mobile services and technologies, including smartphones and near-field communication (NFC), 


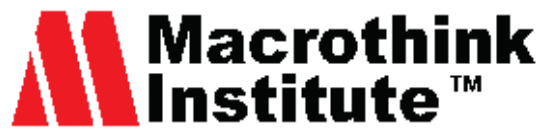

Business and Economic Research

ISSN 2162-4860

2014, Vol. 4, No. 2

will reduce the need to deploy expensive point-of-sale (POS) terminals and further push for higher adoption rates. However, according to A.T. Kearney, evidence seem to indicate that there may be a ceiling to cash displacement and that a completely cashless society will either come about at a glacial pace or remain "mission impossible" (ibid.).

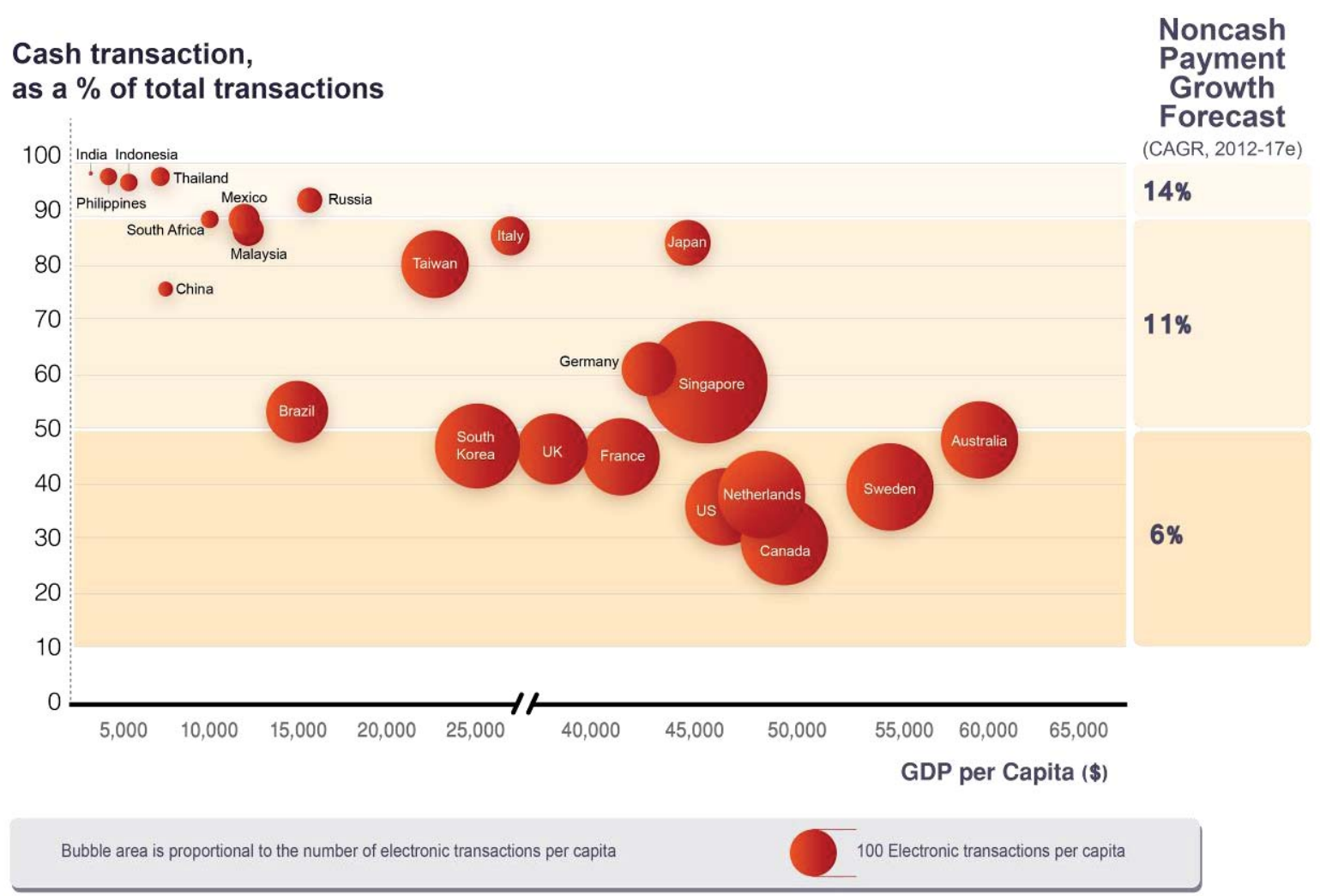

Figure 1. Noncash penetration vs. GDP per capita vs. expected growth. Source: Menon et al., 2013

On the dimensions of simplicity, reliability, digital cash methods are likely to become more competitive with cash over the next five years (Menon et al., 2013). But issues of trust and security will still remain the most challenging factors to overcome (Al-Khouri, 2014a; 2014b). Governments and apart from their regulatory role, are expected to play a more active role in supporting digital payment infrastructures and platforms. Modern government identity management systems for example are argued to provide advanced identification and authentication solutions (ibid.). Such systems would provide higher levels of protection to build confidence to conduct electronic transactions. In fact, the use of government identity management systems is envisaged to likely become an integral part of digital payment systems in countries like $\mathrm{GCC}^{1}$ in the few years to come.

GCC stands for Gulf Cooperation Council, also called the Cooperation Council for the Arab States of the Gulf (CCASG), which was established in 1981 to promote coordination between member states in economic and social spheres. It includes six countries: Bahrain, Kuwait, Oman, Qatar, Saudi Arabia, and the United Arab Emirates. The GCC population is estimated to be around 40 million. 


\section{MlMacrothink}

Business and Economic Research

ISSN 2162-4860

2014, Vol. 4, No. 2

The purpose of this paper is to provide a brief overview of digital payments, some changes in the field and the subsequent advantages. It also attempts to provide a high level overview of the potential role of modern government identity management systems to provide higher levels of trust and security in digital payment systems. This is examined in connection to a pilot project underway in the United Arab Emirates (UAE) to improve participation in the national Wages Protection System (WPS).

This article is structured as follows. In section 2, we provide some background information on the evolution of money and some of the underlying concepts. We also explain shortly how technological progressions and socioeconomics have contributed to the emergence of digital payment systems. In section 3, we provide a short overview of the rising cost of cash production. In section 4: we highlight the global shift towards digital payments and the trend of cashless transactions. In section 5, we elaborate on a number of critical factors hindering wider adoption of digital payments as well as the opportunities that are promoting them. In section 6, we provide an overview of how the government of United Arab Emirates (UAE) envisages to use its national smart identity card in its Wages Protection System (WPS).

\section{Evolution of Money}

In order to realise the importance of digital payments, the progression of money through history must be considered. Money is simply a commodity to be exchanged with items of similar worth, which in trade's early days was for an exchange of goods or services. The barter system, where a trader exchanged their goods for other items they need, including taxes in exchange for safety from a leading figure, and its modern incarnations is losing favour to these modern payment methods.

\subsection{The Concept of Money}

Many people do not have the opportunity to swap goods or services. Also, the barter system cannot deal with more complicated problems and of course does not provide quick satisfaction to the consumer. There is also the issue determining a realistic value of the exchanged items, which brought about the need to store value. This was not feasible with the barter system, as the items involved were usually not long lasting (such as food). See Figure 2.

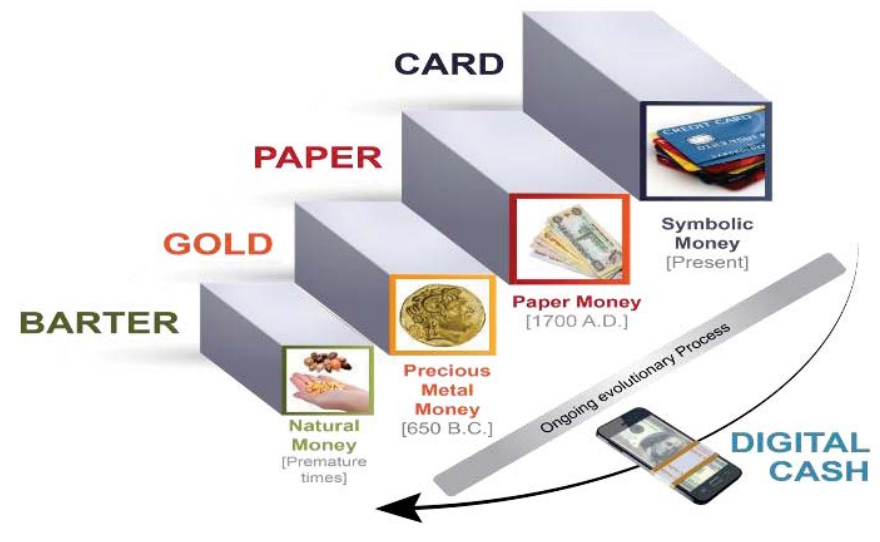

Figure 2. Evolution of money. 


\section{Mll Macrothink}

Business and Economic Research

ISSN 2162-4860

2014, Vol. 4, No. 2

As a result, the concept of currency was created, starting out as metal tokens, stamped by the government to represent legal tender as this new definition of currency. Larger monetary exchanges and greater trade opportunities were necessary for the government to produce new jobs for the state, so formal documents acknowledging debt were created (called currency) as to persuade people to use them instead of goods or services. Gold is the equivalency commodity of paper money for governments all over the world, so anyone can exchange their paper money for a certain amount of bold. This is not always the case as many states decide the value of their currency as they see fit, which can lead to serious problems.

This was possible up until 1970, but technological progressions and socioeconomic issues (e.g. inflation), made currency lose its appeal, as it was no longer feasible for people to hold increasingly large amounts of coins and paper. Furthermore, paper money can easily be stolen or lost, so banks needed to come up with a new solution, which were variations of paper money, including cheques and bank guarantees. However, these had other shortcomings and so the problem persisted.

As a result, the definition of "money" is connected with how valuable something is considered to be, along with the truth that an exchange will provide instant satisfaction and can be saved to be used in the future. Money is controlled by the efficient management of value exchange, so the possibility that value perception drops can be eliminated almost and the participants in an exchange are provided instant satisfaction.

Risk is an important factor when considering the idea of money. There is a chance that a seller is not given the value of their items or services provided, or conversely the buyer does not receive the items or services themselves. Traditionally, trust between seller and buyer was essential and there were verbal and in-person agreements regarding transactions, however in recent times many exchanges can be anonymous and faceless, so there is an increased chance of risk.

Accordingly, a rising number of these anonymous internet transactions bring the need for value exchanges to be executed. Physical money is unable to be used over these electronic mediums for physical services and as a result, the definition of money is shifted. Currently, currency needs to cover two key issues regarding value exchange, which are risk mitigation (conveying trust between two parties over a mutually agreed value exchange) and allowing for storage of value for any future use.

Traditional currency does not cover these two purposes, as they are physical items, and as goods and services are exchanged over digital means, money itself also needs to be digital. This shift is now permanent, so "digital money" can now be seen as a service itself, which will be usable in many transaction types, as any other service would be in line with the perceived value of the exchange.

The concept of salary can be used as an example here, as this is "credit" for work being performed. In turn, the credit is used to purchase goods and services to cover that person's needs. This can continue until the credit is reduced until the account is finally empty and cannot perform any other transactions. 


\section{Ml Macrothink}

Business and Economic Research

ISSN 2162-4860

2014, Vol. 4, No. 2

Bridgewater (2011) explained payment life cycles as having five principles, as depicted in Figure 3. This can help illustrate the idea of money, as an experience of payments and choices to make these transactions with, handling any connected risks in these transactions to the value exchange, enabled by payment agreement services which can help honour these exchanges.

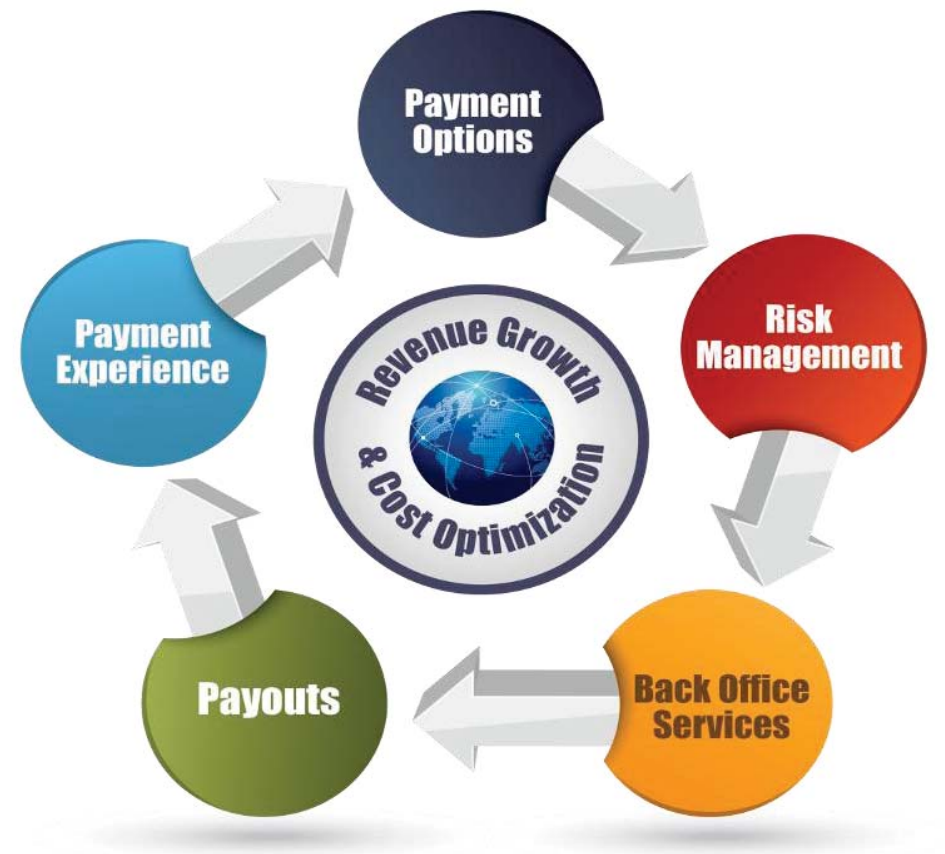

Figure 3. Digital River - Five Principles of Payment Lifecycle Management

\section{The Rising Cost of Cash Production}

Many countries are having difficulty in creating enough cash, as the costs for this process rise along with the needs to transport. Recent numbers from the US Mint are shown in Figure 4.
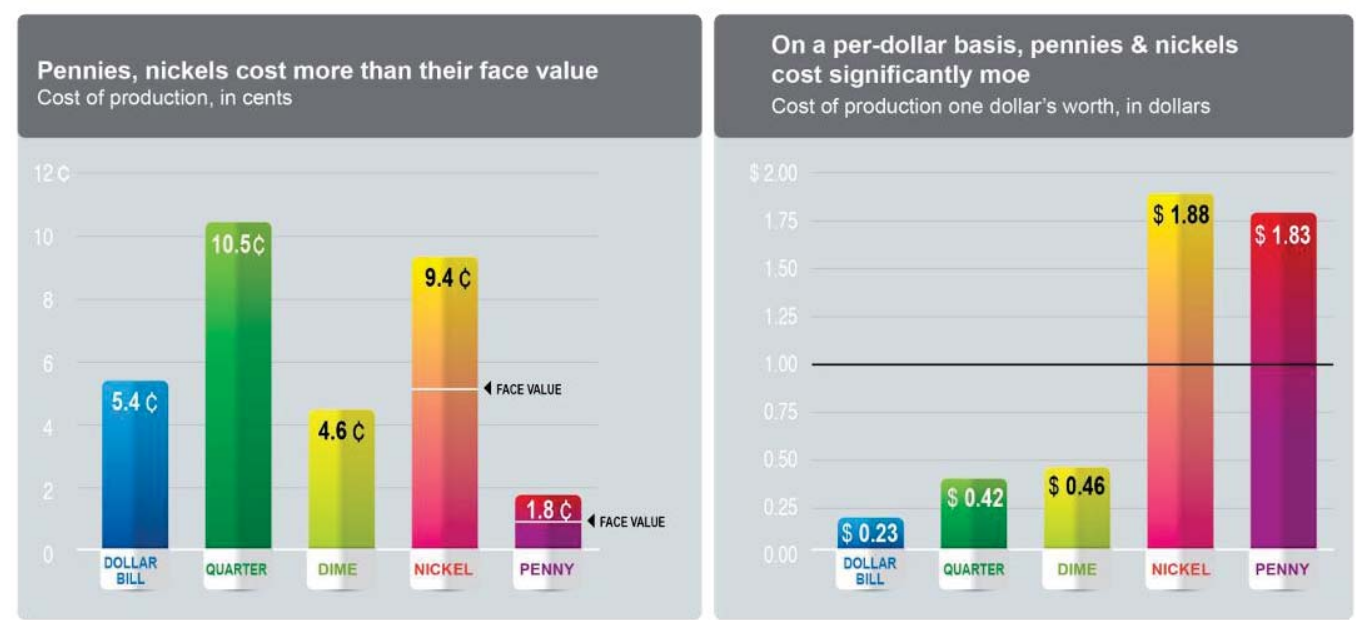

Figure 4. Cost of $\mathrm{Cash}^{2}$

Source: U.S. Mint, Federal Reserve cited in: Ingraham (2014)

\footnotetext{
${ }^{2}$ The average coin is circulated for 25 years, while the average dollar bill lasts 5.9 years. The value for the dollar bill reflects the cost to produce multiple bills over a 25 year period.
} 


\section{MInstitute Macrothink}

Business and Economic Research

ISSN 2162-4860

2014, Vol. 4, No. 2

The process of creating smaller denominations of a currency costs more than the actual value of the currency (Ingraham, 2014; Raskin and Kolet, 2013; Zielinski, 2012), with pennies and nickels costing twice their face value to create, and the dime only breaking even. A quarter, on the other hand, offers less than half its value to the state. This issue is multiplied by inflation being less in nations with goods and services costs a quarter or a dime. Thus, the state is unable to stop producing these smaller denominations and this is also why the dollar bill cannot cease production. Along with other drivers, the rising cost of cash production is certainly pushing for developments in the field of digital payments.

\section{Digital Money / Payments}

Digital money (also referred to as electronic money, digital currency, or e-cash) comes in two basic forms; computer networks and digital stored value systems (Cohn, 2001; EU, 2014). In recent years there has been considerable interest in the development of digital money schemes (Al-Laham et al., 2009). Digital money is viewed to have the potential to take over from cash as the primary means of payments (ibid.). In fact, digital money is widely argued to have greater potential to replace central bank currency (Al-Laham et al., 2009; Berentsen, 1997). This clearly indicates that the advent of digital money will have an impact on the overall banking system and monetary policy (ibid.).

Using cards, Internet payments are broadly supported and advertised. Governments are shifting their operations online as to allow their service payments to be conducted there. This is the aforementioned change from a sociological act to a technological one. Figure 5 shows example nations and the amount of payments they conduct without using cash.

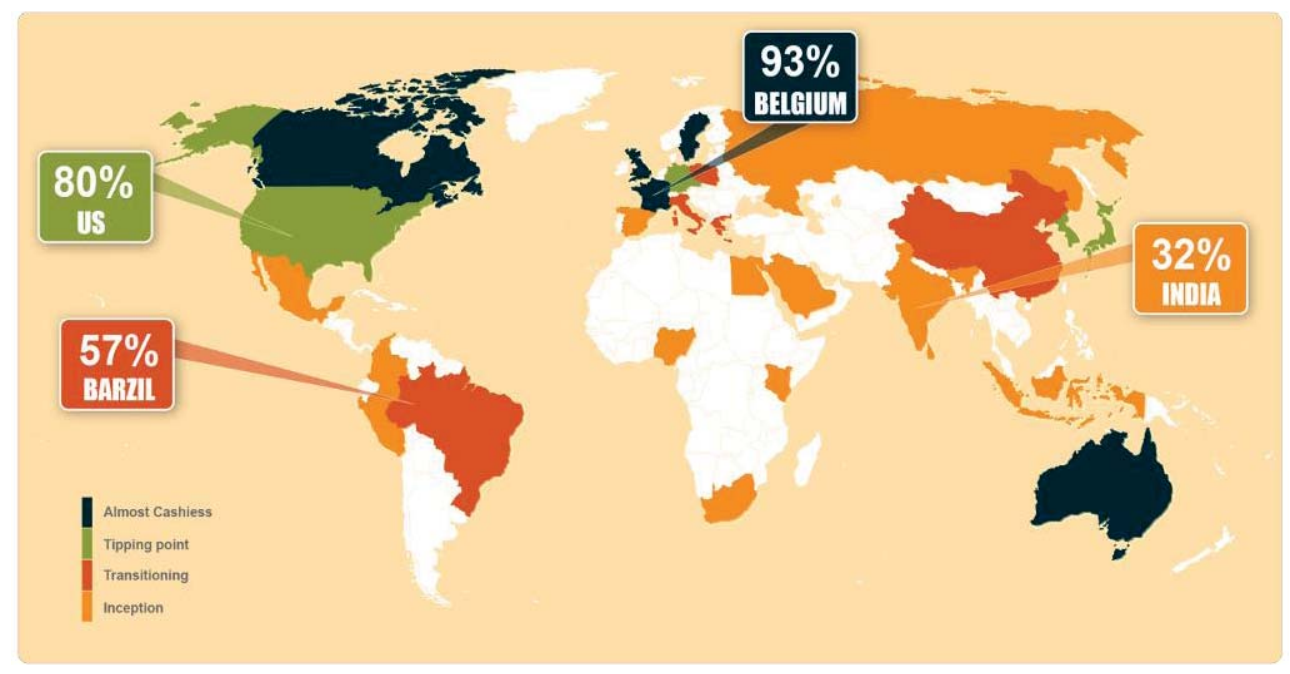

Figure 5. The evolution of a cashless society

Source: Kelly and Pisa (2013)

Figure 6 provides another illustration of some key findings from a MasterCard study released in 2013 that shows the growth of cashless share with respect to certain economies (Thomas et al., 2013). 


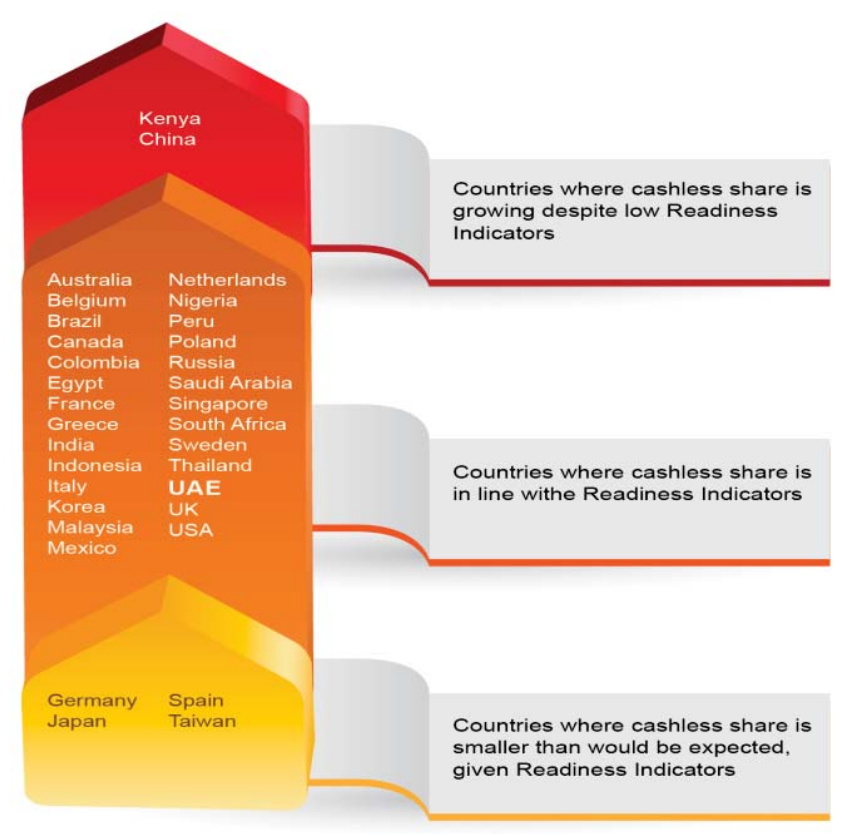

Figure 6: Growth of cashless economies

Source: (Thomas et al., 2013)

According to MasterCard study, of the $\$ 63$ trillion in total global consumer spend in 2011, 34 percent (\$21 trillion) was done with cash, while cashless payments accounted for 66 percent (\$42 trillion) (Thomas et al., 2013). Consumer payments for goods and services accounted for about $11 \%$ of the value of payments around the globe, but this still represented more than $90 \%$ of volume of payments (or number of transactions). Cash accounted for $60 \%$ of the value of total retail payments in shops or online, but when other large consumer payments (e.g. wire transfer to buy a car, direct debit to pay mortgage) were included, the value of payments represented by cash fell to $34 \%$. See Figure 7.
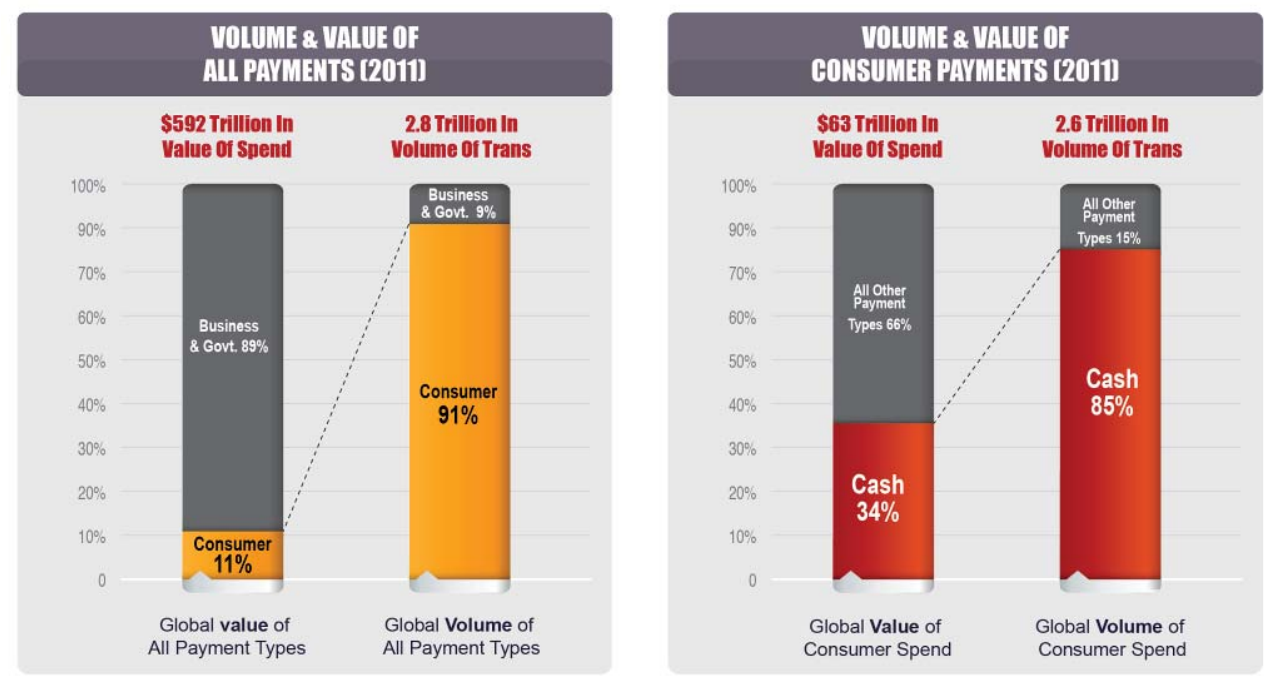

Figure 7. Global value and volume of payments

Source: Thomas et al., 2013 


\section{MlMacrothink}

Business and Economic Research

ISSN 2162-4860

2014, Vol. 4, No. 2

This sudden increase in electronic transactions is due to the multiple advantages cashless payments hold over paper money. Cash cannot be entirely forgotten in favour of digital payments, but there is a clear trend of needing more cashless transactions.

\section{Prospects of Digital Payments}

Today, around $85 \%$ of all retail payment transactions are done with cash, which equates to $60 \%$ of retail transaction value (Thomas et al., 2013). MasterCard research indicated that the degree of readiness to move to a cashless society is determined by factors like the accessibility and affordability of financial services; the scale and market share of retailers; the level of technology that is available; and participation of consumers in the formal economy (ibid.). See also Figure 8.

\begin{tabular}{|c|c|c|c|}
\hline & Cash & Cashless today & Cashless in 5 years \\
\hline Simple & $\begin{array}{l}\text { As easy as taking it out of your } \\
\text { wallet }\end{array}$ & Need to sign or enter a PIN & $\begin{array}{l}\text { Swiping your mobile on an NFC } \\
\text { reader }\end{array}$ \\
\hline Reliable & Always works & $\begin{array}{l}\text { Card doesn't read; } \\
\text { POS connection is slow }\end{array}$ & $\begin{array}{l}\text { Improved systems uptime and } \\
\text { connection reliability }\end{array}$ \\
\hline Safe & $\begin{array}{l}\text { You can only lose what's in your } \\
\text { wallet }\end{array}$ & Identify theft, INN number attacks & $\begin{array}{l}\text { New technology, such as } \\
\text { encryption and biometrics }\end{array}$ \\
\hline Private & $\begin{array}{l}\text { Difficult to trace, shadow } \\
\text { economy }\end{array}$ & Every transaction is recorded & $\begin{array}{l}\text { New privacy laws; new technology } \\
\text { enables privacy option }\end{array}$ \\
\hline Free & \multirow{2}{*}{$\begin{array}{l}\text { No cost to take money out of } \\
\text { your wallet }\end{array}$} & \multirow{2}{*}{\multicolumn{2}{|c|}{ MDR charged to merchants; surcharge often added }} \\
\hline & & & \\
\hline \multirow[t]{2}{*}{ Universally Accepted } & \multirow{2}{*}{$\begin{array}{l}\text { Accepted everywhere and } \\
\text { anytime }\end{array}$} & & \\
\hline & & \multicolumn{2}{|c|}{$\begin{array}{l}\text { Not accepted universally (for example, at small } \\
\text { merchants or members of different payment systems }\end{array}$} \\
\hline
\end{tabular}

Figure 8. Consideration factors for cashless solutions3

Source: (Menon et al., 2013)

The factors exhibited in the above diagram represent important areas of consideration, that need to be addressed if digital payments are assumed to take a more predominant role. While it is too early to think that cash would be completely replaced by digital payments, available evidence indicates that we are indeed moving in that direction. Advantages of digital payments are too huge to be ignored. We shortly elaborate on these opportunities in the next sub-sections.

\subsection{Personal and Economic Security}

As there is no traditional paper money involved in an electronic exchange, safety is less of an issue as there is no physical item to be stolen or lost. As a result, security concerns will be less costly which can also help reduce insurance costs, and illegal money laundering activities would be significantly reduced, as all exchanges will be traceable and transparent, and tax can be tracked. The provision of social benefits can become more efficient because of this transparency, and these activities can be ensured to be in line with regulations. As a result,

${ }^{3}$ PIN is personal identification number; NFC is near-field communications; POS is point of sale; IIN is issuer identification number; MDR is merchant discount rate. 


\section{MlMacrothink}

Business and Economic Research

ISSN 2162-4860

2014, Vol. 4, No. 2

electronic exchanges allow these actions to become more beneficial to a country's economy.

\subsection{Payment Cards}

Trusted transaction payment acquisition and settlement are the crucial parts of this kind of system. Banks are continuously attempting to provide credit cards and debit cards to their clients, supported by payment processing systems. This is to allow their current client base to conduct their business electronically. Payment processing systems are synergistic with banks to handle the exchanges at point of sale stations, cash machines and web applications. These use the cards and allow transactions to go through, supported by a rapid increase in the number of digital payments worldwide.

\subsection{Forecasted Growth in Mobile and Digital Payments}

According to Cap Gemini's World Payments Report in 2013, supported by a huge demand and use of smart phones and internet, mobile and electronic payments are estimated to rise by over $1 / 2$ yearly to almost 30 billion transactions in 2014 (Capgemini, 2013). Digital payments are estimated to rise by almost $1 / 5^{\text {th }}$ annually over the same time frame to almost 35 billion transactions (ibid.).

It was also mentioned that developing areas regions participate in these non-bank based exchanges through electronic and mobile means, or prepaid credit cards and virtual currency. As a result, new suppliers in the financial sector are appearing, creating mobile wallets and pre-paid credit cards for clients to use digitally. Example cases include Kenya and Uganda where telecom operators handle payment disbursal.

Subsequently, money has once again become a sociological issue, as finance is much easier to access through digital means, which allows a wide range of users to exchange electronically and fairly without any consideration of social standing.

\subsection{Security of Digital Systems}

There are of course unique issues, hurdles and limitations to these new solutions. Security in these digital transactions is crucial in order to build trust, which is considered vulnerable. Also, it is not possible to definitely identify the user of the bankcard or mobile devise during a transaction digital tender is considered a non-government supported modality, so its credibility is brought into question. The advantages of these setups are irrefutable; however there are still trust issues. Bankcards issuers attempt to counter this by concentrating on fraud prevention and risk mitigation methods. According to a Pew Internet Research on Future of Money Multifactor report, authentication will be critical to digital payment system progression (Smith et al., 2012). This is where government identity management systems come into play!

\section{The Potential Role of Government Identity Management Systems: The Case of UAE}

The necessary identification and authentication methods in digital payment systems are thought to be facilitated in the future by modern national identity management frameworks (Al-Khouri, 2014b). In the United Arab Emirates, for example, the government provides its nationals and legal residents with an identity card, through a federal government organization 


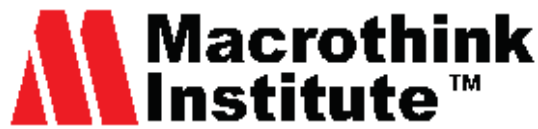

Business and Economic Research

ISSN 2162-4860

2014, Vol. 4, No. 2

called Emirates Identity Authority. This card contains a wide range of credentials to verify electronic transactions, acting as a digital ID. When used in relation with digital payment applications, the smart ID card is seen to provide advanced capabilities ranging from encryption, digital signatures, and strong authentication mechanisms. This setup is thought to be a catalyst for a great amount of change in the country with regards to social and financial participation.

On a different note, the UAE uses a unique Wages Protection System (WPS) to make sure all of their low paid workers are safe, through frequent and transparent wages distribution. However, the banks cringe away from these services through cards as the costs are too high. As a result, salaries are pooled and distributed by exchange houses and other non-banking institutions (Al-Khouri, 2014b).

The government of the UAE is working towards connecting its WPS system to the national ID cards of the beneficiaries. This would allow workers to withdraw their wages from any participating bank, and can also add funds to their cards for other transactions. This is also viewed to support breakthrough in micro payments and transactions in the UAE. Figure 9 illustrates a high level model of the use of the smart ID card as a verification and authentication medium to support trust and security in the WPS system.

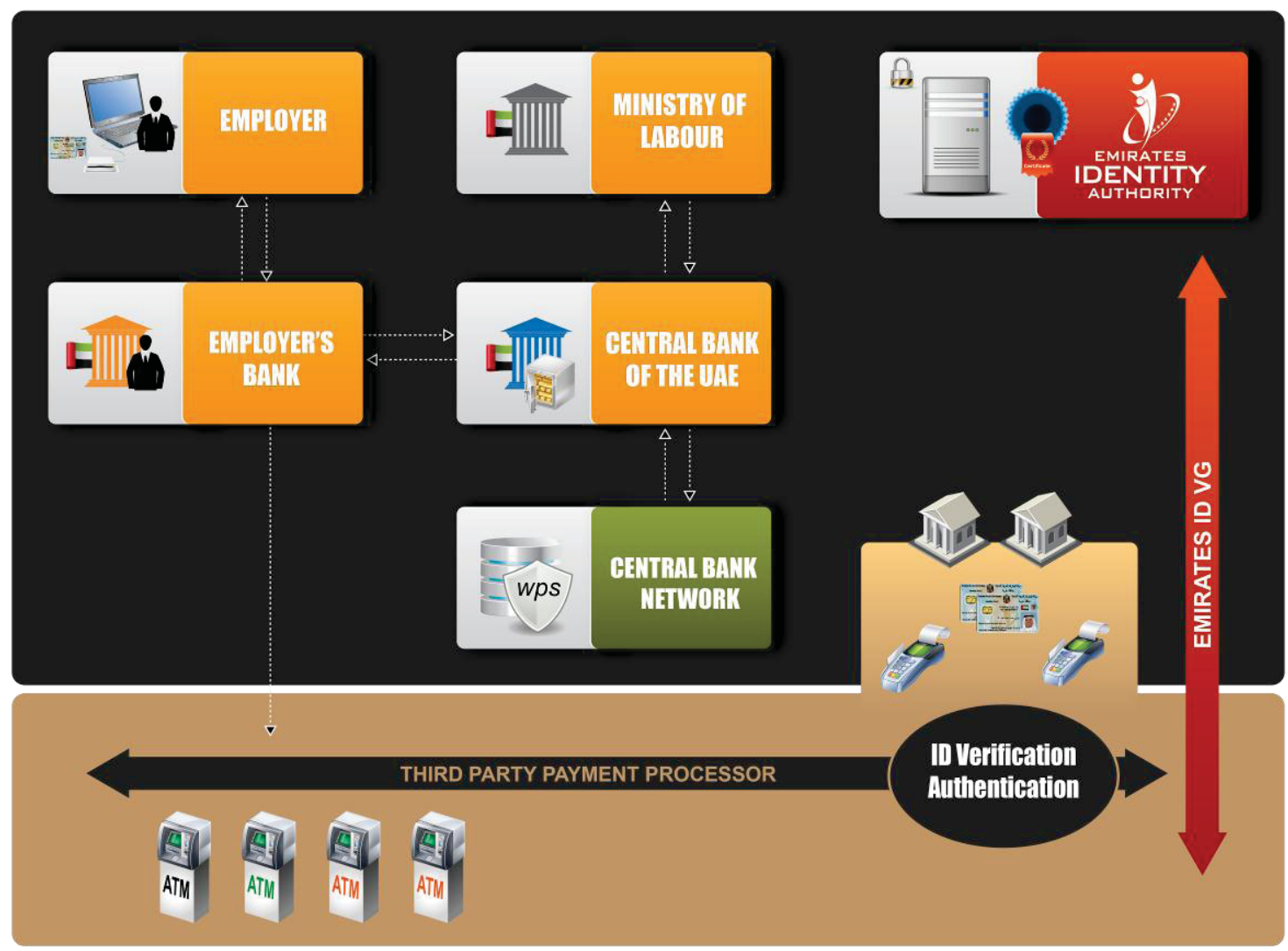

Figure 9. High level illustration of UAE ID card usage in WPS system

Besides, by allowing wider access to micro payments and micro transactions with the national smart ID card, dependent women, children, the elderly can go through with exchanges of their own, whereas normally they not be given any bank cards. A reserved estimation points to over 


\section{Mll Macrothink}

Business and Economic Research ISSN 2162-4860 2014, Vol. 4, No. 2

$\$ 4$ billion in new transactions through unbanked women and young adults using these new ID cards for micropayments. The WPS system is estimated to allow $\$ 20$ billion per year to be spent by the 4 million citizens of the UAE. As a result, the global opportunities for such a setup would be huge beyond estimation.

\section{Conclusion}

This paper highlights the fact that there is evidence that electronic payments will have a great impact on society in the future and the increasing cost of cash production, along with control and security issues, will propagate this electronic shift. Governments will play a significant role in any such fundamental change.

Governments using identity centered managements methods could offer unrivalled security in personal identification and authentication, systems which are crucial in resolving and preventing any identity related risks of digital payments, thus allowing for safer exchanges. In turn, this increases trust, a key element to the success of digital payment systems.

The technological developments in the field of digital payments are promising for interesting times to come. No doubt, that it is a matter of few or less years until we see many applications of digital payments around us that will be performed with "a wave of a mobile or a gesture with a wearable device, such as Google Glass or a smart watch" (Menon et al., 2013). But we are poised to believe that the future is holding auxiliary opportunities for more innovative developments in the field yet to be unleashed.

\section{References}

Al-Khouri, A. M. (2014a). Identity Management in the Retail Industry: The Ladder to Move to the Next Level in the Internet Economy. Journal of Finance \& Investment Analysis, 3(1), 51-67.

Al-Khouri, A. M. (2014b). Electronic Payments: Building the Case for a National Initiative. Advances in Social Sciences Research Journal, 1(3), 176-195. http://dx.doi.org/10.14738/assrj.13.221

Al-Laham, M., Al-Tarawneh, H., \& Abdallat, N. (2009). Development of Electronic Money and Its Impact on the Central Bank Role and Monetary Policy. Issues in Informing Science and Information Technology, 6, 339-349.

Berentsen, A. (1997). Digital money, liquidity, and monetary policy. First Money, 25 Nov. [Online] Available: http://dx.doi.org/10.5210/fm.v2i7.538

Booz \& Company. (2010). Leaving Cash Behind: The Rise of Electronic Payments in the MENA Region. [Online] Available: http://static.wamda.com/web/uploads/resources/Leaving_Cash_Behin.pdf

Bridgewater, P. (2011). Payment Lifecycle Management-Keep Your Online Customers Engaged. [Online] Available: http://digitalriverblog.com/category/payments/

Capgemini. (2013). World Payments Report 2013. [Online] Available: 
http://www.capgemini.com/resource-file-access/resource/pdf/wpr_2013.pdf

Cohn, B. J. (2001). Electronic Money: New Day or False Dawn? Review of International Political Economy, 8(2), 197-225. [Online] Available: http://dx.doi.org/10.1080/09692290010033376

Dovetail. (2012). The Rising Tide of US Electronic Payments. [Online] Available: http://www.dovetailsystems.com/pdfs/DovetailWhitepaper_RisingTideOfUSElectronicPayme nts.pdf

European Central Bank. (2012). Virtual Currency Schemes. [Online] Available: http://www.ecb.europa.eu/pub/pdf/other/virtualcurrencyschemes201210en.pdf

European Central Bank. (2014). Opinion of the European Central Bank on Limitations of Cash Payments. [Online]

Available:

https://www.ecb.europa.eu/ecb/legal/pdf/en_con_2014_4_f_sign.pdf

European Union. (2014). E-money, The EU Single Market. [Online] Available: http://ec.europa.eu/internal_market/payments/emoney/index_en.htm.

FairCash, Evolution of Payment Instruments. [Online] Available: http://faircash.org/technology.html

Humphrey, D. B., Pulley, L. B., \& Vesala, J. M. (1996). Cash, Paper, and Electronic Payments: A Cross-Country Analysis. Journal of Money, Credit and Banking, 28(2), 914-939. http://dx.doi.org/10.2307/2077928

Ingraham, C. (2014). Taxpayers lost $\$ 105$ million on pennies and nickels last year, The Washington Post. [Online] Available: http://www.washingtonpost.com/blogs/wonkblog/wp/2014/03/10/taxpayers-lost-105-millionon-pennies-and-nickels-last-year/

Kelly, T., \& Pisa, K. (2014). MasterCard Advisor Report 2013, Payments Council, CUBIC Transportation Systems, BIS data. [Online] Available: http://edition.cnn.com/2014/07/02/business/is-a-cashless-society-on-the-cards/

Menon, N., Guedeney, H., Kittikhoun, K., \& Narasimhan, S. (2013). Cash Displacement: The Final Threshold. A.T. Kearney. [Online] Available: http://www.atkearney.com/web/digital-business-forum/detail/-/asset_publisher/VMEx2L1Phj PS/content/cash-displacement-the-final-threshold/10192

Raskin, M., \& Kolet, I. (2013). Minting Coins Cost U.S. Taxpayers \$436 Million: Chart of the Day, Bloomberg. [Online] Available: http://www.bloomberg.com/news/2013-02-20/minting-coins-cost-u-s-taxpayers-436-millionchart-of-the-day.html

Smith, A., Anderson, J. Q., \& Rainie, L. (2012). The future of money: Smartphone swiping in the mobile age, Pew Research Center's Internet \& American Life Project, Washington, D.C. [Online]

Available: 


\section{Macrothink}

Business and Economic Research ISSN 2162-4860 2014, Vol. 4, No. 2

http://www.pewinternet.org/files/old-media/Files/Reports/2012/PIP_Future_of_Money.pdf

Sumanjeet, S. (2009). Emergence of Payment Systems in the Age of Electronic Commerce: The State of Art, Asia Pacific. Journal of Finance and Banking Research, 3(3), 18-40.

Thomas, H., Jain, A., \& Angus, M. (2013). MasterCard Advisors' Cashless Journey: The Global Journey From Cash to Cashless. [Online] Available: http://newsroom.mastercard.com/wp-content/uploads/2013/09/Cashless-Journey_WhitePaper FINAL.pdf

VISA International. (2003). The Virtuous Circle: Electronic Payments and Economic Growth. [Online] Available: http://www.visacemea.com/av/pdf/eg_virtuouscircle.pdf

Zielinski, M. (2012). Cost to Make Penny and Nickel Rises, Annual Loss Reaches $\$ 116.7$ Million, Coin Update. [Online] Available: http://news.coinupdate.com/cost-to-make-penny-and-nickel-rises-1139

\section{Copyright Disclaimer}

Copyright for this article is retained by the author(s), with first publication rights granted to the journal.

This is an open-access article distributed under the terms and conditions of the Creative Commons Attribution license (http://creativecommons.org/licenses/by/3.0/). 